\title{
FAMILY AGROINDUSTRIAL PROPERTIES AND RESISTANCE: FORTIFICATION OF THE SMALL RURAL PROPERTIES FROM CAPARAÓ CAPIXABA
}

\author{
Aramis Cortes de Araujo Junior \\ Federal Institute of Espírito Santo Campus of Alegre \\ https://doi.org/10.35410/IJAEB.2020.5577
}

\begin{abstract}
The objective of this paper is to carry out the cartographic and social mapping of the properties of the rural family agro-industry of the city of Ibatiba, located in the planning micro-region of Caparaó capixaba. We believe that stimulating research with local family agro-industries can contribute to the increasement of employment and income creation, settlement of man in the countryside and maintenance of local social and cultural relations in order to preserve the symbolic inheritance and identity, proving that adding value to the natural product produced in these properties can be extremely valorous for another development and envolvement proposal that is adequate to what has traditionally been done in the premises of family properties.
\end{abstract}

Keywords: Agroindustry, Family farming, Resistance, Public policy.

\section{INTRODUCTION}

Approximately six years ago we started studies about the geographic reality of the city of Ibatiba, Espírito Santo, according to what has been seen in other research projects. However, with the deepening of knowledge and understanding of the local reality we figured out the strongest and weakest economic points of the locality and we inserted new studies and social theories that can apprehend the phenomena totality that have potential to be studied.

We intend in this proposal to map all the agro-industrial family units located in the city of Ibatiba, Espírito Santo, with the perspective about the potential for employment creation, income and competition in order to a possible autonomy in relation to the large food companies that supply goods in commercial establishments.

To select which agro-industries will be held in this work we will refer to Agne and Waquil (2011, pp. 151-

152) with the following criteria: "the development of at least one agroindustrial activity, whose characteristics are processing activity of agricultural production in its own establishment, with the use of family labor (MIOR, 2005), the commercialization of agroindustrial production and the linkage with family farming, that is, management and production coordinated by the family"(WANDERLEY, 2001).

From this objective, we agree with Prezzoto (2002) when this author mentions a new perspective for the rural environment by mentioning the expression "sustainable rural environment" which 
aims to provide the current model of capitalist development with another productive pattern that works alternatively to the conventional model which has already been proved to be predatory, unequal and unjust.

According to Marin and Trentin (2010, p. 38), reflect upon sustainable rural development is a social and economic alternative because it envisages to insert local characters into discussions and decision-making processes and provide protection to the environment.

To Carmo (1998), a research effort is necessary towards a transition to a new agriculture, in which the maintenance and increase of soil fertility, the preservation of other natural resources and the permanence of the cultural values of the rural populations are parts of a development model with new forms of production and social organization, without the risk of crystallizing sustainable agriculture away from social reforms (MARIN, TRENTIN, 2010, 38).

Therefore, to think about agro-family production brings to the researcher the need to relate this activity to a whole set of characteristics that takes into account the diversification and/or integration of "animal and vegetable activities, and by working on smaller scales, it can represent the ideal locus for the development of a sustainable agriculture to all environments "(MARIN, TRANTIN, 2010, p.40).

The great debate of this research is the study of familiar agriculture as a form of promotion of small producers and the raising of this model to a prominent place in the agrarian scenario as highlighted below:

Family agriculture should occupy a prominent place in autonomous processes of agroindustrialization, as a way to strengthen its capacity for social reproduction. According to this scope it raises the need for public policies in favor of the various forms of agroindustrialization, ranging from the informal market to the niche market, organic products and of differentiated quality (MARIN, TRANTIN, 2010, p. 40 apud MIOR, 2005 p. 73).

Following this line of action our research fits the aspirations of rural social movements for the struggle to conquer new market space without losing the originality and also the social, cultural and historical characteristics of family agriculture. Therefore, when we aim to study family agroindustries we are adopting what Alentejano calls pluriactivity, that is:

Pluriactivity is characterized by the of agricultural use diversification, with the multiplication of complementary strategies for the reproduction of the farmers, which also involves the use of other activities, urban wage labor or the industrial and handcrafted transformation of agricultural production, whether it is the development of tertiary activities (services and leisure) inside the rural property (ALENTEJANO, 1999, p. 155 apud MARIN; TRANTIN, 2010, p. 41).

Therefore, the quote below complements:

In this new role of pluriactivity or many functions, the creation of small agroindustries can be pointed out as one of the economic alternatives for the permanence of family agriculture and for a new model of sustainable development 
construction, which considers the rural sector as a whole and not only related to agricultural production anymore (MATTEI, 1998 apud PREZOTTO, 2002, p.137).

This new reality directs the rural to the search for new needs of strategies for survival and social reproduction that insert new ways of collecting money for families that are beyond being simply linked to agricultural production.

\section{DEVELOPMENT}

Throughout the history of Brazilian agriculture, small family farmers have always been marginalized by public policies that favored agribusiness and their foreign multinational interests.

According to Lopes and Gerolamo (2005, p. 02), we glimpse a study of small agroindustrial rural properties as a model of resistance to the increasing scenario of the large companies strength, and also to know that these family properties are responsible for a large number of jobs generated in the countryside, for the reduction of the rural exodus and for Brazilian food supply.

In this direction, we propose an action strategy that aims to contribute to small agroindustrial properties through creation of family farmers' networks which carry out relational cooperation and, thus, they can enter consumer markets for their products.

Family farmers need to add value to their in natura production for this insertion. Agroindustry comes precisely with the possibility of adding value to production and allowing greater independence of the producer face to the primary products sector middlemen. With this double cooperation family farmers can build networks that empower economic development and qualitative change in production, moving from the natural good to the integration of production into industry and services.

The authors mentioned in the passage below give light to the importance of family farming in this context:

Ehlers (1999) reports that family-based production systems are a counterpoint to socalled boss farming, characterized by large estates and the use of wage paid labor. Today in Brazil there are about 6.5 million family establishments versus five hundred thousand employers' establishments. The potential to maintain existing jobs or even generate new jobs is therefore much greater in family farming (LOPES; GEROLAMO, 2005, p. 05).

Prezotto (2002 apud MARIN; TRENTIN, 2010, p.42) points out the family agroindustrial activity as a favorable alternative that has the potential to reverse the crisis scenario of agricultural production in Brazilian countryside. Since the country field is no longer exclusively producing food, agroindustry is creating jobs, income, settling man in the country field and 
socially integrating small farmers into a broad and comprehensive network of non-agricultural activities.

And what are the possible benefits that can come from the country field? Prezoto helps us in this mission:

The processing of fruits into candies and beverages, canning preparation in general and the manufacture of cheese, sausage and the processing of agricultural products (drying, sorting, cleaning) and/or processing of raw materials generating new products of animal or vegetable origin, such as milk into cheese and fruit into candies and beverages (PREZOTO, 2002, p.137).

Following this proposal, Marin and Trentin (2010, p.43) cover the family agro-industry with tourism as a way to operate the potential for small-scale agriculture even more positively. In the studied city there is an initiative of a tourist association called Geturi (Rural Tourism Management Association of Ibatiba), but it still needs more public and institutional support to take off.

As an alert we take the words of Marin and Trentin (2010) to expose that:

It must be said, however, that agroindustrialization does not represent the solution to all the problems or needs of family farmers or rural people at all. It should be understood and worked out as part of a set of actions and other activities articulated among themselves that seek to build rural development in social, environmental, cultural and economic aspects, based on family farming (MARIN, TRENTIN, 2010, pp. 43).

Many researches made in Brazil highlight family agroindustries as:

Culture preservation, alternative family income, family income diversification, maintenance of the family in rural areas, etc. Although these information, the investigation need to know how these families build commercial opportunities to this production (AGNE; WAQUIL, 2011, p.150).

It is important to realize that the passage above ratifies the need of a direction, in other words, we need family agroindustries network production, but it is necessary more specific knowledge and researches about the socioeconomic reality in those particular areas. The creation process of family agroindustries in the South of Brazil not always will be the best model for Espírito Santo, for example; to implement it as a successful model it is necessary to adapt the model to each municipality.

The immersion in these agroindustries networks becomes clearly important to small farmers because of the main role of the association between them which results in economic gains. The networks, according to Agne e Walquil (2011, p. 155), can be interpreted through the different ties among rural producers. 


\begin{abstract}
The understanding of social relations joint is a characteristic of the network markets because in its definition, there is a connection among people through social relations, making an intricate web "schematically", which points are represented by people and lines - the connection that put them together (BARNES, 1987). This network understanding is good, because it allows us to discuss about the various social relations those family develop in the community and, also, with the people who will buy their products, agents and urban organizations. (AGNE; WAQUIL, 2011, p. 157).
\end{abstract}

What we should have in mind is that this small network of agroindustries should look for expanding their family participants in order to allow the market keep conservation and quality of their products. It means there would not be a competition, but rather a cooperation among people who belong to this network in order to maintain a certain constancy of markets and, thus, it could lead to more confidence in those agroindustries: "Among many activities, farming productivity industrialization represents a way of diversification and an alternative income to family farms" (AGNE; WAQUIL, 2011, p. 158).

As we can see by the text below, the perspective of a network organization helps family agroindustries to develop:

In this context, the family agroindustries use different strategies with the purpose of being more competitive to market, structuring themselves in many ways to buy farm inputs and raw materials, as well as to improve communication and product marketing (CENCI, 2007). For this purpose, according to Fensterseifer (2000), the network model interorganizational cooperation becomes an adequate strategy because institutions have higher probabilities to improve their competitive performance through public actions. (LEONARDI et al, 2010, p. 43).

Nevertheless, small agroindustries do not survive with only victories. An opposite side exists, that is, organizational and legal problems (sanitary, tributary, etc.) which may result in obstacles to their development. According to Leonardi et al (2010, p. 48), the issues are related to agriculture and livestock, health, environment, consumer protection, taxing, labor, pension, physical structure (machinery, facilities,training), the costs to the implementation of these machines and facilities (and the training related to those), among other issues, can become an interference to the formalization of small agroindustries.

These issues are defining to the implementation: registration, production and family products marketing. There is also a whole lobby created by the big agroindustries to make it economically harder for the small competitors to join the market. For this reason, the fostering for the development of small agroindustries is of great importance because they are "like processing plants which may not be employing many people directly, but they certainly employ many indirectly, fixing the man in the countryside and in small towns" (LAUSCHNER, 1995 apud LEONARDI et al, 2010, p.48). The authors assert that: 
In spite of the difficulties created by the law and the inspection system, the insertion of the small farmers in cooperation networks can represent a positive course in order to make small familiar farms competitive. Thus, the participation of local agents, labor unions, associations, governmental and educational institutions and the interaction among those in order to make these networks competitive can provide efficiency over the stages related to production, logistics, marketing, and others. Another extremely relevant topic to familiar agribusiness development is represented by incentive policies promoted by city halls, governments and various types of organizations, which have been looking forward to defining new strategies in order to consolidate the familiar agroindustry and contribute to the fixation of man in the country and small towns. (LEONARDI et al, 2010, p. 48).

Another important point that also should be mentioned is the issue about equivalence in various requirements, such as sanitary demands, which occur between the small familiar agroindustries and the big national/foreign industries. Such fact should be studied to highlight the way these not equivalent requirements turn projects related to small farmers and small agroindustries unviable. As Leonardi et al (2010, p. 54) show, the consequences to these small agroindustries which "process food by artisanal or homemade level, with small production scale, end up not meeting the law requirements, staying informal".

Another aspect seen as an obstacle by the analysis of the interviews, which are also related to the sanitary law, is the limitation of the places where small business family farmers can sell their products. The restriction happens because, according to Brazil federal law n. 7.889/89, from 1950, the trade of products inspected by the municipal inspection can only be done on the agroindustry town perimeter. (LEONARDI et al, 2010, p. 54).

What are the examples of agroindustries products being manufactured by small properties? The most diverse products are being manufactured on small properties and we believe that, with the right incentives and public policies the list of products should grow and, consequently, increase the revenue of the small farmers. Amorim e Staduto (2008, p. 26) show some of the products commercialized after researching this segment:

The feedstock is transformed on the following products in familiar agribusiness: tea, swine derivatives (sausages, lard, crackling, smoked meat and stuffed piglets), packed greenery, organic products (greenery, fruits, soy, corn), shredded semiorganic chicken, fruits, dried tomato, baked goods (biscuits, cake, bread, sweet loaf, snacks), sugar cane derivatives (brown sugar, sugar cane syrup, sugar cane candy, sugar cane brandy), peanut derivatives (peanut brittle bar, paçoca), milk derivatives (cheese, cream cheese, butter, cream), liquor, pasta (agnoline, noodles, tortelli), seasoned salt, canned greenery, jams, candies (jelly and chimíer), honey, propolis, pamonha (traditional Brazilian baked corn candy), wine, vinegar, juice and alcohol soap (AMORIM; STADUTO, 2008, p. 26).

We must understand that familiar agroindustrialization has always existed and has always been part of everyday life in small rural properties with the use of artisanal and traditional familiar methods of preparing the final products. 
For this reason, Sulzbacher $(2009$, p. 2) states that small farmers have initially started producing artisanal products in their own kitchens in order to minimize their dependency to nature and to avoid relying on the primary agricultural production, increasing diversity and durability of the food products prepared.

In addition to that, the agroindustry becomes a new form of contemporary synthesis since it symbolizes the union between the old and new respectively represented in the rural rationality (production relations and know-how) and the corporate rationality (management, administration and inspection that suit the market needs) (SULZBACHER, 2009, p. 2).

The new relation between traditional knowledge and corporate management is the new in this process, being a stimulus to the agroindustry processing. It now involves sanitary and managerial practices closer to the market requirements. However, it is important to ratify that it is not something new to the small rural properties which already have had the know-how on this production process.

Therefore, it can be observed, contradictorily, that agribusiness is enhanced where agriculture's [and the rural area] modernization developmental paradigm could not reach its fullness: the agroindustry emerges from the developmental logic based on a knowledge thought as archaic and which was left out of the rural development process. (SULZBACHER, 2009, p. 2).

Therefore, the goal of this research goes beyond mapping: we look forward analyzing Ibatiba rural area (a small town in Espírito Santo) reality and those who are part of it, searching alternative proposals to the idea that agribusiness development is the only way of promoting the wellness of countrymen. On the other hand, we try to understand how this rural area can overcome the existent barriers to the autonomous socio-economic development of the local small farmer - both quantitative and qualitative - looking forward to contributing to its social reproduction which goes beyond economic, but goes cross political, cultural, historical, folkloric and also identity, symbolic, sustainability, among other aspects.

Among the factors that stimulate artisanal food production revaluation, we find changes the agrifood industry has been experiencing in the last decade. A process which familybased agriculture farms become 'small production farms' and "shows growing strategic competitive advantage because of its market awarded features: they are associated to tradition, nature, to local and artisanal production" (WILKINSON, 2003, p.04). In this case, it needs to follow a set of production standards that are meant to guarantee product quality, or as said by Wilkinson (2003, p. 05), when alluding to the rescue of the 'small farmer' traditional idea as a market strategy. There is the need of a mix of the reinvention of the old traditions and the adoption of new practices, as far as these traditions now have the endorsement of a demanding urban consumer. (SULZBACHER, 2009, p. 6).

\section{FINAL CONSIDERATIONS}


Finally, considering the results obtained with this research so far in small familiar agribusinesses, in the town of Ibatiba, in Espírito Santo, we are able to identify the following products being manufactured:

\section{Picture 1: Agro-industrial products identified}

\begin{tabular}{|l|l|}
\hline Cheese & Bread and Cake, biscuits, candies, chocolate \\
\hline $\begin{array}{l}\text { Embedded derivatives (sausages, bacon, black } \\
\text { pudding, crackling), smoked and/or stuffed pieces }\end{array}$ & Cassava and corn flour \\
\hline $\begin{array}{l}\text { Dairy products } \\
\text { Wine }\end{array}$ & Coffee, Thin hominy \\
\hline $\begin{array}{l}\text { Sweets (jelly, sugar cane candy, cane syrup, } \\
\text { brown sugar, etc.) }\end{array}$ & Organic Grape \\
\hline Corn baked candy and Corn cream & Agritourism (local restaurants and stores) \\
\hline Dried tomato, banana, dehydrated pineapple & Boutique beer \\
\hline Spices (garlic) & Packaged/ready-to-consume greenery \\
\hline
\end{tabular}

Source: Trabalhos de campo (Country work), Cortes, 2018.

To our questions, the small agroindustries are capable of breaking the hegemonic pattern associated to the agribusiness that deeply affects the existing power relations between local versus global. The strengthening of the small producer aims at loosening this interdependent system in which they are linked and giving economic autonomy to the ordinary production while also giving them cultural autonomy preserving its traditions, signs, parties, customs, and its traditional lifestyles that often go contrary to the colonial modernity that imposes its "rationality" to the traditional knowledge. (PORTO-GONÇALVES, 2015).

We believe studying this sector means to provide a voice to powerless people in the country, showing there is a strong resistance stemming from marginalized territories by stiff hierarchies imposed from top to bottom. (BALLESTRIN, 2013). And, for such purpose, we searched from the strategies created by these small family farmers to remain on the country, as an example, the associations and fairs created by small producers, which are maintained with much effort for State aid to these strategies.

\section{REFERENCES}

AGNE, C. L.; WAQUIL, P. D. Redes de proximidade: agricultores, instituições e consumidores na construção social dos mercados para os produtos das agroindústrias rurais familiares na região central do RS. REDES, Santa Cruz do Sul, v. 16, n. 1, p. 149 - 171, jan/abr. 2011.

AMORIM, L.S.B.; STADUTO, J.A.R. Desenvolvimento territorial rural: a agroindústria familiar no oeste do Paraná. Revista de Economia Agrícola, São Paulo, v.55, n.1, p.15-29, 2008. 
BALLESTRIN, L. América Latina e o giro descolonial. Revista Brasileira de Ciência Política, $\mathrm{n}^{\circ}$ 11, Brasília, mai-ago 2013. p. 89-117.

LEONARDI, A.; BORGES, J. A. R.; FREITAS, J. B. de; SCARTON, L. Redes de cooperação em

agroindústrias familiares: a Casa da Quarta Colônia. Teoria e Evidência Econômica, Ano 16, n. 34, p. 42-59, jan./jun. 2010.

MIOR, L. C. Agricultura familiar, agroindústria e desenvolvimento territorial. Colóquio Internacional de Desenvolvimento Rural Sustentável, 2005.

LOPES, R. J.; GEROLAMO, M. C. Redes de Pequenos Produtores Rurais como Fonte de Vantagem Competitiva Sustentável: Estudo de Caso dos Pequenos Produtores de Limão do Interior do Estado de São Paulo. In: XXIX ENANPAD, 2005, Brasília - DF, 2005.

MARIN, M. Z. TRENTIN, C. E. G. Desenvolvimento rural: análise das agroindústrias familiares de Campinas do Sul-RS. Revista Perspectiva, Erechim - RS, v. 34, n. 127, p. 35-51, set. 2010.

PORTO-GONÇALVES, C. W. A globalização da natureza e a natureza da globalização. $6^{\mathrm{a}}$ ed. Rio de Janeiro: Civilização Brasileira, 2015.

PREZOTTO, L. L. Uma concepção de Agroindústria de pequeno porte. Revista de Ciências Humanas, UFSC, CCFCH. n. 31, Florianópolis: EDIUFSC, 2002.

SULZBACHER, Aline Weber. Agroindústria familiar rural: caminhos para estimar impactos sociais. XIX Encontro Nacional de Geografia Agrária, São Paulo, 2009, pp. 1-25

WANDERLEY, N. Raízes históricas do campesinato brasileiro. In: TEDESCO (Org.) Agricultura familiar: realidades e perspectivas. Passo Fundo-RS: UPF, 2001. 